\section{Single Gallium Nanoparticle Displays Optical Phase-Change Memory}

Memory devices based on phase changes have the potential to supplant electronic memories due to their greatly reduced size and power consumption. In addition, crystalline-to-crystalline transitions exhibited in polymorphic systems may provide higher base logic than current binary systems. It has been previously demonstrated that single Ga nanoparticles exhibit lightinduced structural phase changes with different dielectric properties. Recently, B.F. Soares, F. Jonsson, and N.I. Zheludev from the Optoelectronics Research Centre, University of Southampton, United Kingdom, have demonstrated that a single Ga nanoparticle undergoing light-induced phase changes acts as an all-optical, rewriteable, quaternary memory element (i. e., a memory element with four stable logic states).

As reported in the April 13 issue of Physical Review Letters (DOI:10.1103/ PhysRevLett.98.153905), the researchers used the atomic beam from an effusion cell and a light-assisted deposition technique to grow an 80-nm Ga nanoparticle at the 30-nm aperture of the tip of a gold-coated tapered fiber, which was kept at $80 \mathrm{~K}$. The nanoparticle was then connected to an external fiberoptic and placed in a cryostat. The four observed memory states, referred to as $0,1,2$, and 3 , correspond to three different crystal structures and the Ga liquid. The researchers first activated the transitions to the four states sequentially by heating the nanoparticle slowly from $100 \mathrm{~K}$ to $160 \mathrm{~K}$. Switching nonsequentially between the nanoparticle's four states, that is, writing information to the nanoparticle, was achieved with single laser pulses while sampling the nanoparticle's reflectivity with pump-probe lasers, operating at a much lower intensity than the write laser, corresponds to reading the information. The researchers switched between different logical states in a controlled manner, thereby demonstrating the memory functionality. Moreover, higher order logical functionality was shown by switching directly from the ground state to any targeted higher state. For example, at $120 \mathrm{~K}$, switching from state 0 to state 1 was accomplished with a $1.5 \mathrm{pJ}$ pulse of 1- $\mu$ s duration while a $4.85 \mathrm{pJ}$ pulse of 1 - $\mu$ s duration switched 0 to 3 . After exposure to the optical pulses, the nanoparticle remained in state 3 even after the ambient temperature was reduced to $100 \mathrm{~K}$. Returning to the 0 state required a temperature of $100 \mathrm{~K}$ and turning off the read lasers.

The researchers said that "with quaternary memory functionality, one nanoparticle is capable of storing an estimated $0.2 \mathrm{~Tb}$ in $^{-2}$, compared to $0.015 \mathrm{~Tb}^{-2}$ in Blu-ray DVDs, and requires about one-tenth of the energy required to write single bits of information using current state-of-the-art methods. These figures demonstrate the potential for single nanoparticles to provide memory functionality in future highly integrated nanophotonic devices, operating at very low power levels. "

SteVEn TrohalaKi

\section{Ferroelectric $\mathrm{Bi}_{3.5} \mathrm{Nd}_{0.5} \mathrm{Ti}_{3} \mathrm{O}_{12}$ Nanoparticles Synthesized at Low Temperatures}

Ferroelectric materials like the lanthanide-doped bismuth titanates $\left(\mathrm{Bi}_{4} \mathrm{Ti}_{3} \mathrm{O}_{12}\right)$ may be used in nonvolatile memory, sensors, and actuators. Typically, $\mathrm{Bi}_{4} \mathrm{Ti}_{3} \mathrm{O}_{12}$-based materials are synthesized by a solid-state reaction of $\mathrm{Bi}_{2} \mathrm{O}_{3}$ and $\mathrm{TiO}_{2}$. Calcination temperatures in excess of $800^{\circ} \mathrm{C}$ are then required to achieve the perovskite $\mathrm{Bi}_{4} \mathrm{Ti}_{3} \mathrm{O}_{12}$ phase, often resulting in unwanted grain growth and coarsening. P. Prakash, A. Garg, M.K. Roy, and H.C. Verma of the Indian Institute of Technology, Kanpur, India have developed a chemical method to make stoichiometric neodymium-doped bismuth titanate nanoparticles. As reported in the April issue of the Journal of the American Ceramic Society (p. 1295; DOI: 10.1111/j.1551-2916.2007.01539.x), crystalline, stoichiometric $\mathrm{Bi}_{3.5} \mathrm{Nd}_{0.5} \mathrm{Ti}_{3} \mathrm{O}_{12}$ was realized at $\sim 550^{\circ} \mathrm{C}$, nearly $300^{\circ} \mathrm{C}$ lower than conventional techniques.

Nanoparticles of $\mathrm{Bi}_{3.5} \mathrm{Nd}_{0.5} \mathrm{Ti}_{3} \mathrm{O}_{12}$ were made by a chemical route. First, the bismuth $(\mathrm{Bi})$ and neodymium $(\mathrm{Nd})$ precursors were dissolved in citric acid. Ethlyene amine was used to stabilize the solution. Next, acetyl-acetone-stabilized titanium isopropoxide was mixed with the $\mathrm{Bi} / \mathrm{Nd}$ solution. Excess $\mathrm{Bi}(10 \%)$ was added to the solution to overcome Bi loss during heat treatment. The sol was then dried at $110^{\circ} \mathrm{C}$, first while stirring on a hot plate until the sol thickened and then in an ultrasonic bath. The dried powder was then calcined for $1 \mathrm{~h}$ in air at various temperatures ranging over $200-700^{\circ} \mathrm{C}$.

Based on their $x$-ray diffraction and thermal analysis results, the researchers said that the crystallization of $\mathrm{Bi}_{3.5} \mathrm{Nd}_{0.5} \mathrm{Ti}_{3} \mathrm{O}_{12}$ is a two-step process: first, formation of a nonferroelectric $\mathrm{Bi}_{2} \mathrm{Ti}_{2} \mathrm{O}_{7}$ phase at $\sim 310^{\circ} \mathrm{C}$ followed by formation of ferroelectric $\mathrm{Bi}_{3.5} \mathrm{Nd}_{0.5} \mathrm{Ti}_{3} \mathrm{O}_{12}$ nanoparticles with perovskite structure at temperatures at $\sim 500^{\circ} \mathrm{C}$. According to their transmission electron microscopy results, the average particle size for the sample calcined at $550^{\circ} \mathrm{C}$ and $600^{\circ} \mathrm{C}$ is $\sim 50-60 \mathrm{~nm}$. Capacitance versus temperature measurements of the as-prepared samples confirm that the nonferroelectric-to-ferroelectric transition is $\sim 610^{\circ} \mathrm{C}$. The researchers said that the key to the reduced crystallization temperatures of ferroelectric $\mathrm{Bi}_{3.5} \mathrm{Nd}_{0.5} \mathrm{Ti}_{3} \mathrm{O}_{12}$ nanoparticles is the vigorous stirring and ultrasonication during drying, preventing gel formation, which, if formed, inhibits proper mixing of the precursors leading to higher crystallization temperatures and larger sized particles.

JEREMIAH T. ABIADE

\section{Nanosized Pt Particles in Pt- $\mathrm{CeO}_{2} /$ Carbon Black Composite Anode Improve Performance of Direct Methanol Fuel Cell}

Anodes of commercially produced direct methanol fuel cells (DMFCs) are synthesized from an expensive platinum $(\mathrm{Pt})$ and ruthenium $(\mathrm{Ru})$ alloy with limited availability of raw materials for large-scale production. One alternative currently under development is to use a Pt-cerium oxide $\left(\mathrm{CeO}_{2}\right)$ composite supported on carbon black (CB), but research to date has reported lower performance than the standard $\mathrm{Pt}-\mathrm{Ru} / \mathrm{C}$ anode. T. Mori, M. Takahashi, F. Ye, and A. Vinu from the Fuel Cell Materials Center in Japan, in collaboration with $\mathrm{H}$. Kobayshi from Saitama University and J. Drennan from the University of Queensland, have overcome this disadvantage by using nanometer-sized Pt particles to synthesize a $\mathrm{Pt}-\mathrm{CeO}_{2} / \mathrm{CB}$ anode, improving its performance beyond existing formulations and the standard Pt-Ru/C anode.

As reported in the April issue of the Journal of the American Ceramic Society (p. 1291; DOI:10.1111/j.1551-2916.2006.01483.x), the research team based the fabrication process of this material on precipitation and co-impregnation methods, resulting in a $\mathrm{Pt}-\mathrm{CeO}_{2} / \mathrm{CB}$ anode with a uniform distribution of $\mathrm{Pt}$ particles of 7-8 $\mathrm{nm}$ in size. The same technique was used to synthesize the $\mathrm{Pt}-\mathrm{Ru} / \mathrm{C}$ anode, giving a $\mathrm{Pt}-\mathrm{Ru}$ particle size of $4 \mathrm{~nm}$.

Using cyclic voltammetry and chronoamperometry, the researchers measured potential, current density and electrochemical activity. The peak current density of $\mathrm{Pt}-\mathrm{CeO}_{2} / \mathrm{CB}$ was 1.9 times higher than that of Pt-Ru/C, and current density was consistently higher over the range of temperatures measured. The onset potential of the $\mathrm{Pt}-\mathrm{CeO}_{2} / \mathrm{CB}$ anode, measured at a current density of $0.02 \mathrm{~mA} / \mathrm{cm}^{2}$, was lower by $\sim 10 \%$ than that of the Pt-Ru/C anode. The activation energy of the $\mathrm{Pt}-\mathrm{CeO}_{2} / \mathrm{CB}$ anode was half that of the $\mathrm{Pt}-\mathrm{Ru} / \mathrm{C}$ anode. The relationship of current density to potential revealed to the researchers that the controlling mechanism for the anodic reaction on the $\mathrm{Pt}-\mathrm{Ru} / \mathrm{C}$ anode is the sur- 